\title{
Farklı Gübre Uygulamalarının Durgun Su Kültüründe Yetiştirilen Marullarda Verim ve Kaliteye Etkileri
}

\author{
Esra Okudur $^{1 *}$, Nurgül Ercan ${ }^{2}$ \\ ${ }^{1}$ Akdeniz Üniversitesi, Ziraat Fakültesi, Bahçe Bitkileri Bölümü, Antalya \\ ${ }^{2}$ Akdeniz Üniversitesi, Ziraat Fakültesi, Bahçe Bitkileri Bölümü, Antalya
}

Öz

İklim değişikliği, kötü arazi yönetimi, kuraklık ve toprak verimliliğinde azalma gıda eldesinde alternatif üretim sistemlerine gereksinimi önemli ölçüde artırmıştır. Durgun su kültürü sisteminde bitkiler, kökleri suda olacak şekilde su yüzeyinde strafor yardımıyla sabit bir şekilde yüzdürülmektedir. Durgun su tekniği bitki yetiştirme amacıyla tercih edilen en eski, uygulaması en basit ve yapraklı sebzelerin yetiştiriciliğinde dünyada kullanılan en yaygın topraksız tarım tekniği olarak karşımıza çıkmaktadır. Son yıllarda durgun su kültürü yönteminde yetiştiriciliği kolaylaştırma amacıyla gübre firmalarının hazır gübre formülasyonlarını satışa sunmakta oldukları izlenmektedir. Bu çalışmada amaç hazır gübre karışımı ile tam ve \% 50 azaltılmış gübre uygulamalarının durgun su kültüründe yetiştirilen marulun verim ve kalitesi üzerine etkilerini belirlemektir.

Akdeniz Üniversitesi, Ziraat Fakültesi, Bahçe Bitkileri Araştırma ve Uygulama Arazisinde bulunan cam serada gerçekleştirilen bu çalışmada, 3 farklı gübre uygulamasının Confeti marul çeşidinin verim ve kalitesi üzerine etkileri araştırılmıştır. Çalışma tesadüf blokları deneme deseninde 3 tekerrürlü ve her parselde 21 adet bitki olacak şekilde düzenlenmiştir. Çalışmada bitki uzunluğu, bitki köksüz ağırlığı, yaprak sayısı, parsele verim, bitki kök ağırlığı, bitki gövde ağırlığı, bitki gövde çapı, bitki gövde uzunluğu, yaprak boyu, yaprak eni değerleri saptanmış ve SPSS paket programında istatistik analiz yapılmıştır.

Çalışmada bitki uzunluğu, bitki köksüz ağırlığı, yaprak sayısı ve verim bakımından gübre uygulamaları arasında $\alpha=0,05$ seviyesinde fark önemli bulunmuş, bitki kök ağırlı̆̆ı, gövde ağırlı̆̆ı, bitki gövde çapı, gövde uzunluğu, yaprak boyu ve yaprak eni bakımından ise istatistiki önemde bir farklılık gözlenmemiştir.

Anahtar Kelimeler: durgun su kültürü, gübre, marul

\section{The Effects of Different Fertilizer Application on Yield and Quality of Lettuce Grown in Floating Culture}

\begin{abstract}
Climate changes, mismanagement of land, drought and reduction of soil productivity have considerably increased the necessity of alternative production systems. In this system, roots of plant are floated on the water surface by styrofoam. Floating culture is the oldest, simplest and most commonly used hydroponic techniques in the world. In the recent years, it is seen that ready to use fertilizers are put on the market for facilitate the cultivation in floating culture. The aim of this study was to determine the effects of a complete fertilizer, reduced fertilizer (\%50) and ready to use fertilizer applications on quality of lettuce grown in floating culture. This study was carried out in glasshouse at experimental field of the Faculty of Agriculture, Akdeniz University in order to investigate the effect of three fertilizers application on yield and quality of lettuce cv. Confetti. This study was arranged in completely randomized plot design in three replications with 21 plants in each plot. In this study, the mean plant length (cm), plant rootless weight (g), root weight (g), the number of leaves per plant, stem weight (g), stem diameter (cm), stem length (cm), leaf size $(\mathrm{cm})$ were measured. Data obtained from this study were subjected to statistical analysis by SPSS program. As a result of the analysis, parameters significant with $\alpha=0.05$ level was subjected to Duncan test.

In this study, statistically significant differences were determined among the fertilizer applications in terms of plant length, plant rootless weight, leaf number and yield. There were no statistical differences among the fertilizer applications in terms of plant root weight, stem weight, stem diameter, stem length, leaf size and number of leaves per plant.
\end{abstract}

Keywords: floating culture, fertilizer, lettuce

*e-mail: okuduresra@hotmail.com 


\section{Giriş}

Son yıllarda çevresel bir sorun olan küresel ısınmanın etkisiyle birlikte, tarımsal kuraklık ile suyun önemi hissedilmeye başlanmıştır. Suyun bütün canlılar için vazgeçilmez bir ihtiyaç olması, onu daha önemli hale getirmektedir [1]. Suyun kısıtlı bir kaynak haline gelmeye başlamasıyla topraksız tarım su ve gübre kullanım etkinliğini artırması nedeniyle giderek daha da ön plana çıkmaktadır.

Genel bir tanımlama ile topraksız tarım, bitkisel üretimin durgun veya akan besin eriyiklerinde, besin sisinde veya besin eriyiği ile beslenmiş katı ortamlarda gerçekleştirilmesidir [2]. Bu açıdan bakıldığında topraksız tarım, su kültürü (hidroponik) ve ortam kültürü (substrat kültürü) olmak üzere ikiye ayrılmaktadır. Su kültüründe bitkiler besin eriyiği içinde yetiştirilirken [3]; ortam kültüründe bitki kökleri organik, inorganik veya sentetik ortamlar içindedir [2 ve 4] Her iki yetiştirme tekniğinde de bitkilerin besin maddesi ve su gereksinimleri, gelişmeleri için gerekli tüm elementleri içeren besin eriyikleri kullanılarak karşılanmaktadır [5] .

Bitki besin solüsyonu şeklinde bitkilere verilen besin elementlerinden bitkilerin en iyi şekilde yararlanması beklenmektedir. Bitki gelişiminde besin elementlerinin toplam miktarından çok yarayışlı miktarları ön plana çıkmaktadır. Topraksız tarım fikri ilk kez 1600 lü yılların başında ortaya çıkmış, 1930 lu yıllarda gelişmeye başlamışıtır. 1938 yılından itibaren Hoagland ve Arnon tarafından oluşturulmaya başlanan bitki besin eriyik reçeteleri 1950 yılında nihayet bulmuş ve günümüzde hala kullanılmakta olan neredeyse bu sistemin anayasası gibi kabul edilen Hoagland besin eriyiği reçetesi elde edilmiştir. Birçok reçete olmasına karşın hemen hemen hepsi aynı tarifi işaret etmektedir. Kimyasal madde üreticisi firmalar bu besin solüsyonunu araştırma amaçlı kullanıcılar için hazır olarak sunmaktadır.

Yaprağı tüketilen sebzeler grubunda en fazla yetiştiriciliği yapılan ürün marul (Lactuca sativa L) olup, ülkemiz dünya marul üretiminde önemli bir yer tutmaktadır. Ülkemiz 2014 yılı marul üretim miktarı ise 468.513 ton dur [6]. Genellikle taze olarak tüketilen marul, beslenme bakımından özellikle minerallerce zengin bir sebzedir.

Shomaker (1949), marul ve kıvırcık yapraklı baş marulun anavatanının Küçük Asya, Kafkasya, İran ve Türkmenistanı da içine alan bölge olduğunu ve bölgede 2000 yıldan beri tarımının yapıldığını, Dillingen (1956) ise, kıvırcık yapraklı baş marulun yabani formlarına Orta ve Güney Avrupa, Kanarya Adaları, Cezayir, Habeşistan, Kafkasya, Keşmir, Nepal, Sibirya ve Batı Asya’nın Mezopotamya'ya kadar uzanan bölgelerinde rastlandığını, Çin'e kıvırcık yapraklı baş marulun M.S. 600-900 yılları arasında geldiğini belirtmektedir [7].

Marul, özellikle y1l boyunca hidroponik üretim için uygun bir üründür. Marul düşük ışık, düşük sıcaklık ve ssıtma masrafları minimumda tutulması ile yetiştirilebilen bir üründür. Marul yaprağının 100 gramı \%94-95 su , 6-8 mg askorbik asit, 1-1,5 g ham protein, 0,2-0,4 g yağ ve 1,5-2,5 g karbonhidrat, 330 i.u. Vitamin A, 20-25 mg kalsiyum, $40 \mathrm{mg}$ fosfor ve 1,5 mg demir içermektedir [8].

Stuart [9] a göre A.B.D. Hava Kuvvetleri 1945 yılında II. Dünya savaşı sırasında Ascenstion adasında $120 \mathrm{~m}$ uzunluğunda ve $90 \mathrm{~cm}$ genişliğinde 245 adet sebze yetiştirme yatağı tesis etmişlerdir. Toplam $2700 \mathrm{~m}{ }^{2}$ lik üretim alanında hıyar, domates, turp, marul ve yeşil biber yetiştirmişler ve toplam olarak $42.676 \mathrm{~kg}$ sebze üretmişlerdir. Yetiştirilen sebzelerin ortalaması olarak dekardan $17800 \mathrm{~kg}$ sebze elde edilmiştir. Yine 1943 yılında İngiliz Guiana'sının Atkinson sahasında 8.1 dekar yerde kurulan su kültürü sisteminde sebze yetiştirilmiş ve buradan dekara $13.500 \mathrm{~kg}$ ürün elde edilmişsir [10]. Yine 1945 lerde 
Japonya'nın Chofu adasında 20 dekar sera içinde 200 dekar tarla koşullarında; Otsu şehrinde tarla koşullarında 100 dekar su kültürü sistemi tesis edilmiştir. A.B.D'nin Kore, Japonya ve Okinawada'ki silahlı kuvvetleri için bu tesislerden 1947-1957 yılları arasında tahminen 45.400 .000 kg sebze üretildiği belirtilmektedir [11]. Son yıllarda yaprağı tüketilen sebzelerin su kültürü yönteminde yetiştiriciliğinin yaygınlaşmasıyla bu yöntemde yetiştiriciliği kolaylaştırmak amacıyla gübre firmalarının hazır gübre formülasyonlarını satışa sunmakta oldukları izlenmektedir. Bu çalışmada amaç hazır gübre karışımı ile tam ve \% 50 azaltılmış gübre uygulamalarının durgun su kültüründe yetiştirilen marulun verim ve kalitesi üzerine etkilerini belirlemektir.

\section{Materyal ve Yöntem}

Akdeniz Üniversitesi Ziraat Fakültesi, Bahçe Bitkileri Araştırma ve Uygulama Arazisinde bulunan cam serada gerçekleştirilen bu çalışma süresince serada ısıtma yapılmamış, 3 farklı gübre uygulamasının Confeti marul çeşidinin verim ve kalitesi üzerine etkileri araştııılmıştır. Bitkiler, 120x50x30 (boy x en x yükseklik) cm ölçülerinde 180 litre hacme sahip 9 adet plastik tankta yetiştirilmiştir. Bitkileri su yüzünde tutmak amacıyla $120 \times 50 \mathrm{~cm}, 30 \mathrm{~mm}$ kalınlığında strafor plakalar kullanılmıştır. Strafor plakalar sıra arası $12 \mathrm{~cm}$ ve sıra üzeri $15 \mathrm{~cm}$ olacak şekilde $5 \mathrm{~cm}$ çaplı daireler biçiminde kesilerek içlerine $5 \mathrm{~cm}$ çaplı, alt ve yan yüzeylerde delikleri bulunan delikli plastik saksılara aktarılmıştır. Bitkilerin içine perlit eklenerek saksılara aktarılırmış böylece saksı içinde sabit durması sağlanmıştır.

Çalışma tesadüf blokları deneme deseninde 3 tekerrürlü ve her parselde 21 adet bitki olacak şekilde toplam 189 adet marul yetiştirilmiştir. Solüsyonlar hazır gübre karışımı ile tam ve $\% 50$ azaltılmış gübre uygulamalarıdır. Hazır gübre karışımının hazırlanması 1 paketi 100 litre su için hazırlanmış pH ve EC ölçümü yapılmasına gerek kalmadan 1801 tekneye ayarlanmış ve tüm yetiştiricilik boyunca hiçbir müdahalede bulunulmamıştır. Tam ve $\% 50$ azaltılmış gübre solüsyonu hazırlanırken ise çizelge 2 'de belirtilen Hoagland ve Arnon tarafından sunulan bitki besin eriyik reçetesindeki element değerlerine tam olarak uyularak ve su analiz sonucu dikkate alınarak hazırlanmıştır. Çalışmada kullanılan su Akdeniz Üniversitesi Ziraat Fakültesi, Bahçe Bitkileri Araştırma ve Uygulama Arazisinde bulunan su kaynağından alınarak BATEM Laboratuarlarında analiz ettirilmiş ve analiz sonucu çizelge 1 'de gösterilmiştir.

Tam ve \% 50 azaltılmış gübre solüsyonu hazırlanırken $\mathrm{pH}$ ve EC ölçümleri düzenli olarak takip edilmiştir. Solüsyonun pH's 6.0 - 6.5 ve EC'si 1.5-1.7 $\mathrm{mScm}^{-1}$ civarında tutulmuş, $\mathrm{pH}$ yükseldiği zaman $0,1 \mathrm{~N} \mathrm{HNO}_{3}$; düştüğü zaman $\mathrm{NaOH}$ ile ayarlanmıştır.

Çalışmada hava motoru + hava taşı uygulaması ile bitkilere $\mathrm{O}_{2}$ verilerek, her gün bitkilere $\mathrm{O}_{2}$ sağlanmış ve 36. gün uygulama bitirilmiştir.

Uygulamanın 36.günü hasada gelen bitkilerde bitki uzunluğu, bitki köksüz ağırlığı, yaprak sayısı, parsele verim, bitki kök ağırlığı, bitkinin gövde ağırlığı, bitkinin gövde çapı, bitkinin gövde uzunluğu, yaprak boyu, yaprak eni için ölçümler yapılmıştır.

Deneme tesadüf blokları deneme desenine göre 3 tekerrürlü yürütülmüştür. Her parselde 10 bitki üzerinde gözlem yapılmıştır. Denemede elde edilen verilerin değerlendirilmesinde SPSS (Version 17.00; SPSS, Chicago, IL, USA) istatistik paket programı kullanılmış, ortalamaların karşılaştırması Duncan testine göre $\mathrm{P} \leq 0,05$ düzeyinde yapılmıştır. 
Okudur E., Ercan N.

Tablo 1: Su Analiz Sonucu

\begin{tabular}{|c|c|c|}
\hline Lab.No. & 1696 & Değerlendirme \\
\hline pH & 7.24 & Nötr \\
\hline $\mathrm{EC} \mu \mathrm{mhos} / \mathrm{cm}\left(25^{\circ} \mathrm{C}\right)$ & 636 & 2.sinıf(iyi ) \\
\hline EC $\mu \mathrm{mhos} / \mathrm{cm}\left(25^{\circ} \mathrm{C}\right)$ & 0.06 & \\
\hline Kalsiyum(Ca) meq/l & 4.63 & Yeterli \\
\hline Kalsiyum(Ca) meq/l & 1.07 & Düşük \\
\hline Sodyum (Na) meq/l & 0.77 & \\
\hline Karbonat $\left(\mathrm{CO}_{3}{ }^{-2}\right) \mathrm{meq} / \mathrm{l}$ & Yok & \\
\hline Bikarbonat $\left(\mathrm{HCO}_{3}^{-}\right) \mathrm{meq} / \mathrm{l}$ & 5.43 & Orta \\
\hline $\mathrm{Klor}\left(\mathrm{Cl}^{-}\right) \mathrm{meq} / \mathrm{l}$ & 0.93 & 1.sınıf(çok iyi) \\
\hline Sülfat $\left(\mathrm{SO}_{4}{ }^{-2}\right) \mathrm{meq} / \mathrm{l}$ & 1.17 & 1.sınıf(çok iyi) \\
\hline Bor(B) meq/l & 0.03 & 1.sınıf(çok iyi) \\
\hline SAR(meq/l) $)^{1 / 2}$ & 0.45 & Az sodyumlu \\
\hline
\end{tabular}

Tablo 2: Hoagland Besin Eriyiği Reçetesi mg/l

\begin{tabular}{|l|l|}
\hline Element & Konsantrasyon(mg/l) \\
\hline Azot $(\mathrm{N})$ & 210 \\
\hline Fosfor(P) & 31 \\
\hline Potasyum(K) & 234 \\
\hline Magnezyum(Mg) & 48 \\
\hline Kalsiyum(Ca) & 200 \\
\hline Kükürt(S) & 64 \\
\hline Demir(Fe) & 2,5 \\
\hline Mangan(Mn) & 0,5 \\
\hline Bor(B) & 0,5 \\
\hline Bakır(Cu) & 0,02 \\
\hline Çinko(Zn) & 0,05 \\
\hline Molibden(Mo) & 0,01 \\
\hline
\end{tabular}

\section{Bulgular ve Tartışma}

Üç-dört gerçek yapraklı aşamada durgun su kültürüne aktarılan Tolya tohuma ait olan confeti marul çeşidinin fideleri dikimden 36 gün sonra hasada gelmiştir. Soundy ve Smith [12] bahar ve yaz dönemi toprakta marul yetiştiriciliğinde en erken hasat süresini yaklaşık 80 gün olarak bildirmişlerdir. Buna karşın Maboko ve Du Plooy [13] su kültüründe kıvırcık marul için bu sürenin yaklaşık 40 gün olduğunu bildirmişlerdir. Nitekim Wurr vd [14] sıcaklığın artmasıyla hasada gelme süresinin kısaldığını açıklamışlardır. Çalışmada bitki uzunluğu, bitki köksüz ağırlığı, yaprak sayısı, verim, bitki kök ağırlı̆̆ı, gövde ağırlığı, bitki gövde çapı, gövde uzunluğu, yaprak boyu ve yaprak eni bakımından gübre uygulamaları araştırılması yapılmıştır. 


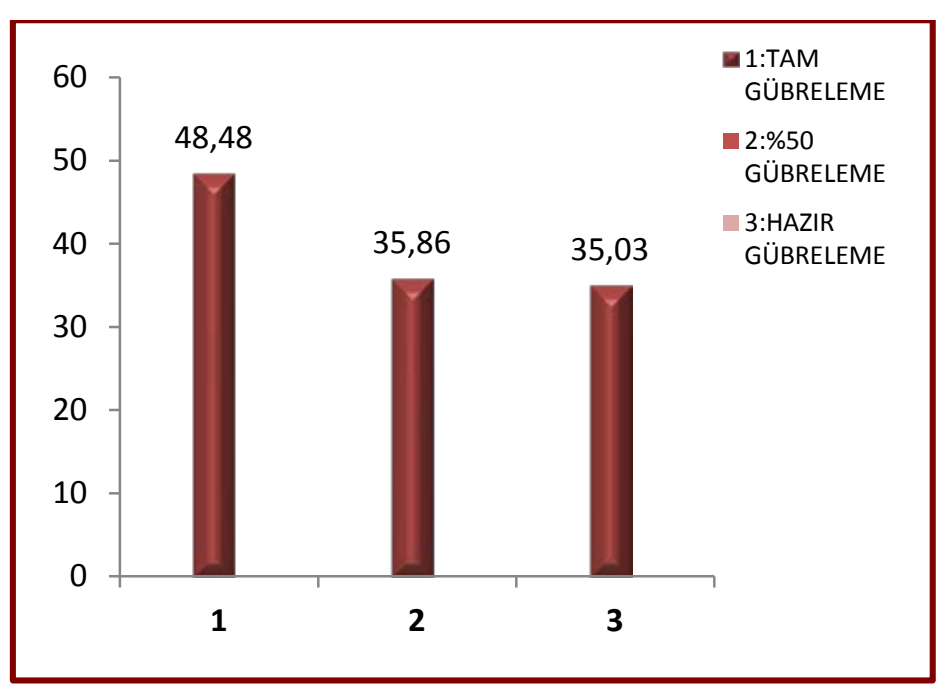

Şekil 1: Bitki uzunluğu(cm/bitki)

\section{Bitki Uzunluğu}

Durgun su kültüründe yetiştirilen marulun verim ve kalitesi üzerine hazır gübre karışımı ile tam ve \% 50 azaltılmış gübre uygulamalarının etkilerini belirlemek amacıyla yapılan bu çalışmada farklı gübre uygulamalarının bitki uzunluğu üzerine etkisi istatistiksel olarak önemli $(\alpha=0,05)$ bulunmuştur. Bitki uzunluğu şekil 1'de de görüldüğü üzere 48,48 cm/bitki ile 35,03 cm/bitki arasında değişmiştir. Bitki uzunluğu bakımından uygulamalar sırası ile tam gübreleme, $\% 50$ gübreleme, hazır gübreleme şeklinde sıralanmıştır. Maboko ve Du Plooy [13] su kültüründe kıvırcık marul çeşitleri ile yaptıkları çalışmada bitki uzunluğunun $17.21 \mathrm{~cm}$ ile $14.38 \mathrm{~cm}$ arasında değiştiğini bildirmişlerdir. Kıvırcık marulda bitki uzunluğu ve bitki çapının yüksek olmasının genellikle pazarlanabilir bitki boyutunun göstergesi olduğunu bildirmişlerdir. Aynı araştırmacıların 2009 yılında yaptıkları çalışmada ise bitki sıklığının artması ile bitki uzunluğunun arttığını, bunun fotosentetik aktif radyasyon (PAR) bakımından bitkiler arasındaki rekabetten kaynaklanabileceğini bildirmişlerdir. Araştırmacılar bu çalışmada bitkileri 10x20, 10x25, $15 \times 20,20 \times 20$ ve $20 \times 25 \mathrm{~cm}$ aralıklarda yetiştirmişler, çalışmada kullandıkları bütün marul çeşitlerinde bitki sıklığının artmasıyla bitki uzunluğunun da arttığını açıklamışlardır [15].

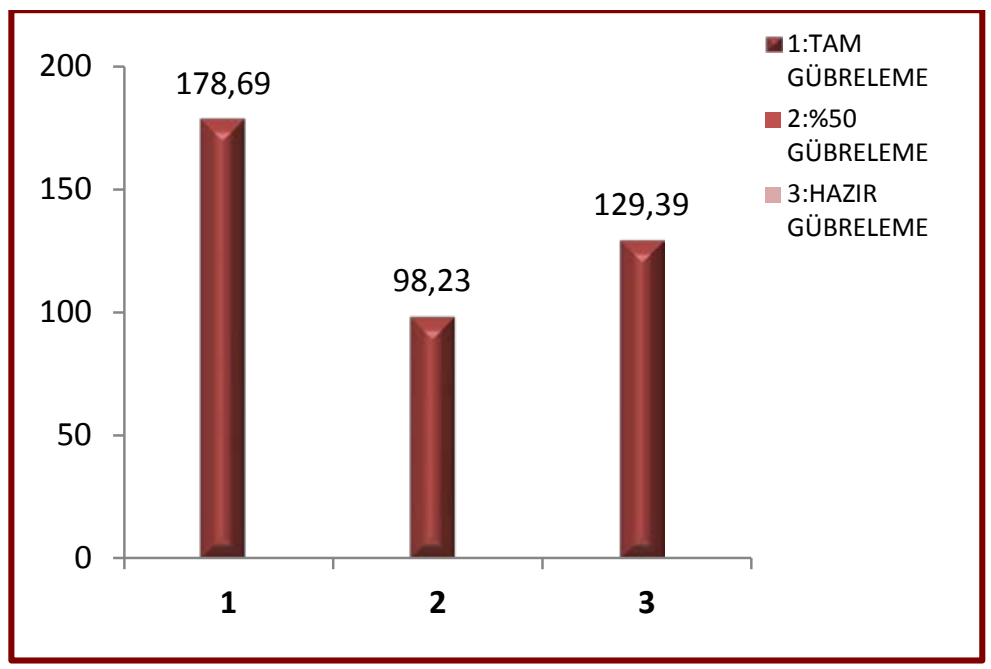

Şekil 2: Bitki köksüz ağırlığı(g/bitki) 


\section{Bitki Köksüz Ağırlığ}

Durgun su kültüründe marul yetiştiriciliğinde farklı gübre uygulamalarının bitki köksüz ağırlığı üzerine etkisi istatistiksel olarak önemli $(\alpha=0,05)$ bulunmuştur. Şekil 2'de de görüldüğü üzere bitki köksüz ağırlığı tam gübre uygulamasında 178,69 g/bitki olarak bulunmuştur. Bunu sırasıyla hazır gübreleme (129.39 g/bitki) ve ,\%50 gübreleme (98,23 g/bitki) izlemiştir. Ercan ve Bayyurt [16] durgun su kültüründe solüsyona oksijen sağlamak üzere hava pompası ve hava taşı uygulamasında en yüksek bitki köksüz ağırlığını 202,4 g/bitki olarak bulmuşlardır. Köksüz ağırlık sadece hava pompası uygulamasında 179,8 g/bitki, ozon uygulamasında ise 144,59 g/bitki olarak bulunmuştur.

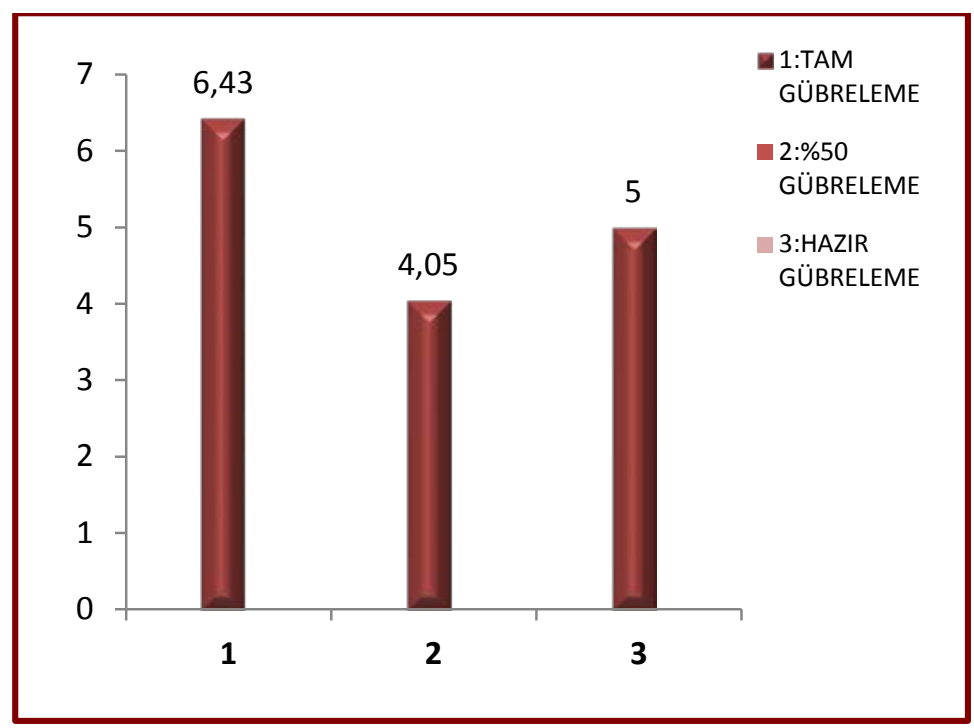

Şekil 3: Verim $\left(\mathrm{kg} \mathrm{m}^{-2}\right)$

\section{Verim}

Durgun su kültüründe marul yetiştiriciliğinde parsele verim şekil 3'de de görülen değerinden hesaplanan verim $\left(\mathrm{kg} \mathrm{m}^{-2}\right)$ değeri üzerine farklı gübre uygulamalarının etkisi istatistiksel olarak önemli $(\alpha=0,05)$ bulunmuştur. En yüksek verim $6,43 \mathrm{~kg} \mathrm{~m}^{-2}$ ile tam gübre uygulamasından alınırken bunu hazır gübre ve \%50 gübreleme uygulamaları istatistiksel olarak birbirinden farksız olarak takip etmiştir. Hazır gübre ve \%50 gübreleme uygulamalarının dekara verim değerleri sırasıyla $5,0 \mathrm{~kg} \mathrm{~m}^{-2}$ ile 4,05 $\mathrm{kg} \mathrm{m}^{-2}$ olarak bulunmuştur. $\mathrm{Bu}$ değerler parsele verim sonuçlarının $\mathrm{m}^{2}$ üzerine hesaplama yapılmıştır. Toth vd [17] durgun su kültüründe üç farklı bitki sıklığında yetiştirdikleri beş marul çeşidinin verimlerini incelemişler ve Bonaly çeşidinin 17 bitki m${ }^{-2}$ sıklığında 4,07 $\mathrm{kg} \mathrm{m}^{-2}$ ile, Tourbilon çeşidinin ise 13 bitki $\mathrm{m}^{-2}$ sıklığında 4,17 $\mathrm{kg} \mathrm{m}^{-2}$ ile en yüksek verime sahip olduklarını bildirmişlerdir. Maboko ve Du Plooy [15] beş farklı sıklıkta $\left(20,25,30,40\right.$ ve 50 bitki $\left.\mathrm{m}^{-2}\right) 4$ kıvırcık marul çeşidi ile yaptıkları çalışmada metre karedeki bitki sayısının artmasıyla yaprak yaş ve kuru ağırlığının artma eğiliminde olduğunu, hızlı büyüme oranı nedeniyle yüksek bitki sıklığında bitkilerin önemli sayılacak ölçüde erken hasada geldiklerini açıklamışlardır. Araştırmacılar baş oluşturmayan marul çeşitleri için en uygun mesafenin 20x20 cm (50 bitki $\mathrm{m}^{-2}$ ) olduğunu ve bu sıklıkta verim ile ilgili parametrelerin en iyi sonucu verdiğini bildirmişlerdir. 


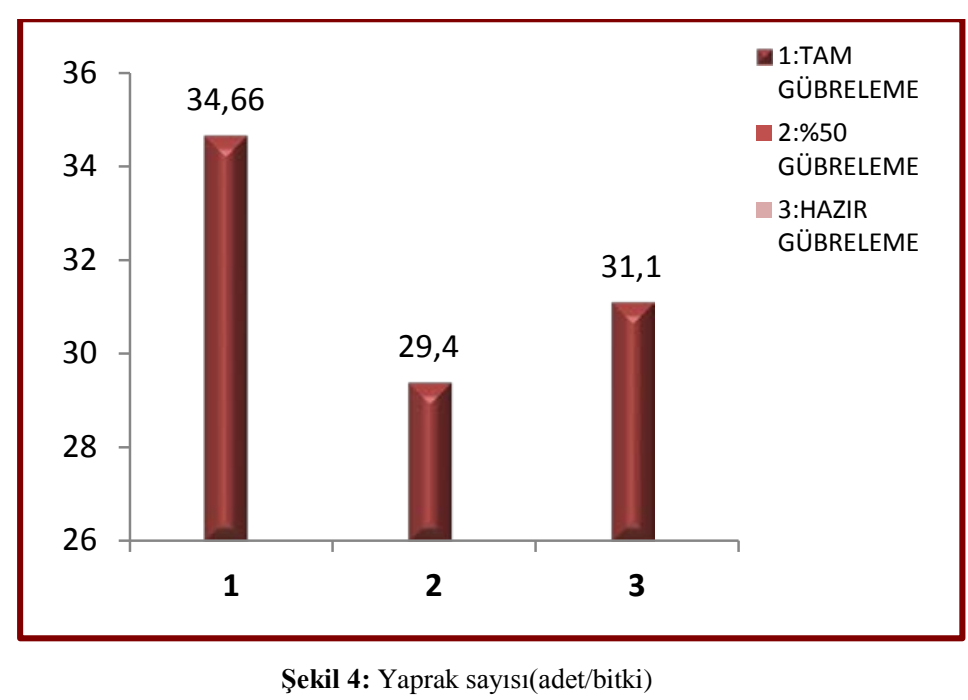

\section{Bitki Başına Yaprak Sayısı}

Durgun su kültüründe marul yetiştiriciliğinde farklı gübre uygulamalarının bitki başına ortalama yaprak sayısı üzerine etkisi istatistiksel olarak önemli $(\alpha=0,05)$ bulunmuştur. En fazla yaprak tam gübre uygulamasından alınmıştır (34,66 adet/bitki). Hazır gübrenin kullanıldığı ortamda yetişen bitkilerde yaprak sayısı 31.10 adet/bitki olarak bulunmuştur. Yaprak sayısı bakımından en düşük değer 29.4 adet/bitki yaprak ile \% 50 gübre uygulamasından elde edilmiştir. Ercan ve Bayyurt [16] durgun su kültüründe solüsyona oksijen sağlamak üzere farklı uygulamaların etkilerini araştırdıkları çalışmada Bohemia ve Delight marul çeşitlerinde bitki başına yaprak sayılarının 28.48 ile 21.3 arasında olduğunu Bohemia çeşidinin daha fazla yaprak oluşturduğunu bildirmişlerdir. Maboko ve Du Plooy [15] su kültüründe farklı bitki sıklığında yetiştirilen marul çeşitlerinde bitki başına yaprak sayısı bakımından Tango ve NIZ-44-675 çeşidinin en fazla yaprak sayısına sahip olduğunu $20 \times 25 \mathrm{~cm}$ sıklıkta Tango çeşidinde 20 adet NIZ-44-675 çeşidinde ise 18 adet yaprak oluştuğunu bildirmişlerdir.

\section{Bitki Kök Ağırlı̆̆ı, Gövde Ağırlığı, Bitki Gövde Çapı, Gövde Uzunluğu, Yaprak Boyu ve}

\section{Yaprak Eni}

Çalışmada farklı gübre uygulamalarının bitki kök ağırlığı, gövde ağırlı̆̆ı, bitki gövde çapı, gövde uzunluğu, yaprak boyu ve yaprak eni üzerine etkisi istatistiki önemde bir farklılık yaratmamıştır. Madzivhandila [18] marulda gövde uzunluğu kısa ve gövde çapı dar olan çeşitlerin sapa kalkmaya karşı dirençli olduğunu ifade etmişlerdir. Maboko ve Du Plooy [13] 16 kıvırcık marul çeşidinin su kültüründeki performanslarını belirlemek için yaptıkları çalışmada, gövde uzunluğunu bakımından en düşük değerin $9.03 \mathrm{~cm}$, en yüksek değerin ise $15.45 \mathrm{~cm}$ olduğunu, gövde çapı için ise en düşük ve en yüksek değerlerin strasıyla 2.43 ile $3.11 \mathrm{~cm}$ olduğunu bildirmişlerdir. 
Okudur E., Ercan N.

Çizelge 3: Bitki uzunluğu, bitki köksüz ağırlığı, yaprak sayısı, parsele verim, bitki kök ağırlığı, gövde ağırlığı, bitkinin gövde çapı, gövde uzunluğu, yaprak boyu ve yaprak eni ölçümlerinin sonuçları

\begin{tabular}{|c|c|c|c|c|c|c|c|c|c|c|}
\hline Uygulamalar & $\begin{array}{c}\text { Bitki } \\
\text { uzunluğu } \\
\text { (cm/bitki) }\end{array}$ & $\begin{array}{c}\text { Bitki } \\
\text { Köksüz } \\
\text { ağırlığı } \\
\text { (g/bitki) }\end{array}$ & $\begin{array}{c}\text { Yaprak } \\
\text { sayısı } \\
\text { (adet/bitki) }\end{array}$ & $\begin{array}{c}\text { Parsele } \\
\text { verim } \\
\text { (kg/parsel) }\end{array}$ & $\begin{array}{c}\text { Bitki kök } \\
\text { ağırlığı } \\
\text { (g/bitki) }\end{array}$ & $\begin{array}{c}\text { Bitki } \\
\text { gövde } \\
\text { ağırlığı } \\
\text { (g/bitki) }\end{array}$ & $\begin{array}{c}\text { Bitki } \\
\text { gövde } \\
\text { çapı } \\
\text { (cm/bitki) }\end{array}$ & $\begin{array}{c}\text { Bitki } \\
\text { gövde } \\
\text { uzunluk } \\
\text { (cm/bitki) }\end{array}$ & $\begin{array}{c}\text { Yaprak } \\
\text { boyu } \\
\text { (cm/bitki) }\end{array}$ & $\begin{array}{c}\text { Yaprak } \\
\text { eni } \\
\text { (cm/bitki) }\end{array}$ \\
\hline TAM & $48,48 a$ & $178,69 a$ & $34,66 a$ & $3,86 a$ & 23,55 & 6,85 & 1,17 & 3,66 & 18,9 & 16,61 \\
\hline \multicolumn{11}{|l|}{ Gübreleme } \\
\hline \multicolumn{11}{|l|}{1} \\
\hline$\% 50$ & $35,86 a b$ & $98,23 b$ & $29,4 b$ & $2,43 b$ & 24,12 & 4,7 & 1,18 & 3,89 & 15,45 & 12,68 \\
\hline \multicolumn{11}{|l|}{ Gübreleme } \\
\hline \multicolumn{11}{|l|}{2} \\
\hline HAZIR & $35,03 b$ & $129,39 a b$ & $31,10 a b$ & $3 a b$ & 29,62 & 7,9 & 1,23 & 4,34 & 17,98 & 14,93 \\
\hline \multicolumn{11}{|l|}{ Gübreleme } \\
\hline \multicolumn{11}{|l|}{3} \\
\hline Sig. & 0,811 & 0,231 & 0,331 & 0,262 & Ö.D. & Ö.D. & Ö.D. & Ö.D. & Ö.D. & Ö.D. \\
\hline
\end{tabular}
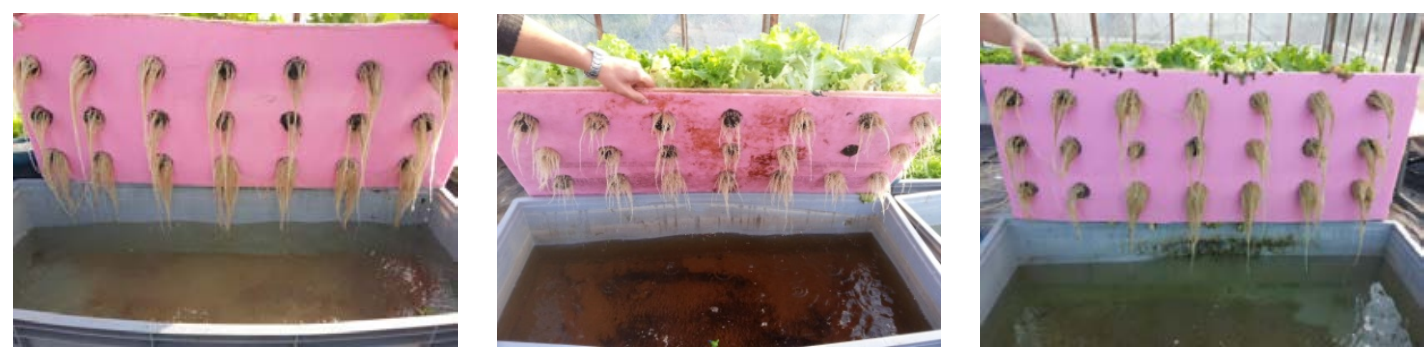

Şekil 5: Tam gübreleme kök görünümü

Şekil 6: Hazır gübreleme kök görünümü

Şekil 7:\%50 gübreleme kök görünümü

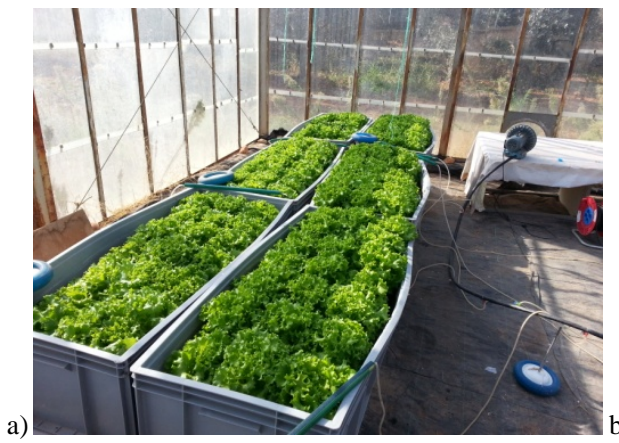

Şekil 8a-8b:Hasada gelmiş bitkilerden görünüm
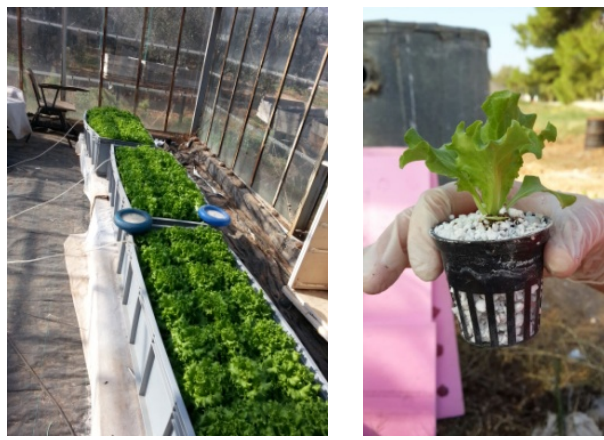

Şekil 9: Fide görünüm

Maboko ve Du Plooy [19], kış döneminde topraksız tarım koşullarında kıvırcık yapraklı baş marul yetiştiriciliği ile ilgili çalışmada ortalama verimin 48,2-105,9 ton/ha; ortalama baş ağırlığının 301,0-661,6 g; ortalama baş çapının 11,4-16,0 cm arasında değiştiğini belirlemişlerdir. Scuderi ve ark., [20],topraksız tarımda kıvırcık yapraklı baş salatada dikim sıklığına bağlı olarak verimin 22 - 39 ton/ha arasında değiştiğini belirtmektedirler.

\section{Sonuç}

Araştırma sonucunda en uzun bitki uzunluğu(48,48 cm/bitki), en ağır bitki köksüz ağırlığı(178,69 g/bitki), en fazla yaprak sayısı(34,66 adet/bitki)ve en fazla verim $\left(6,43 \mathrm{~kg} \mathrm{~m}^{-2}\right)$ tam 
gübrelemede belirlenmiş, hazır gübre kompozesinde bitki uzunluğu hariç diğer ölçümler ikinci sırada saptanmıştır. Test sonucunda bitki kök ağırlığı, bitkinin gövde ağırlığı, bitkinin gövde çapı, bitkinin gövde uzunluğu, yaprak boyu ve yaprak eni arasında önemli bir farklılık gözlenmemiştir.

Çalışmada bitki uzunluğu, bitki köksüz ağırlığı, yaprak sayısı ve parsele verim bakımından gübre uygulamaları arasında $\alpha=0,05$ seviyesinde fark önemli bulunmuş, bitki kök ağırlığı, gövde ağırlığı, bitkinin gövde çapı, gövde uzunluğu, yaprak boyu ve yaprak eni bakımından ise istatistiki önemde bir farklı1ık gözlenmemiştir.

Su kültüründe marul yetiştiriciliğinin yaygınlaşması sonucunda üreticilere kolaylık sağlamak üzere hazır gübre formülasyonlarının yaygınlaşacağı izlenmektedir. Bu konuya öncülük etmek üzere hazır gübre formülasyonu ile yaptığımız çalışmada su kültürüne uygun besin elementi reçetesine göre hazırladığımız tam gübre uygulamasının daha iyi sonuç alındığı saptanmıştır. Ancak su kültürü çalışmalarında yetiştirme mevsiminin solüsyon sıcaklı̆̆ına etkisi, kullanılan suda mevcut elementler ve solüsyonun $\mathrm{EC}$ ve $\mathrm{pH}$ değerlerinin etkili olmasından dolayı hazır gübre formülasyonlarının bahsedilen bu noktalar göz önüne alınarak hazırlanması sonucunda daha başarılı sonuçlar alınacak ve üreticilere büyük kolaylık sağlayacaktır.

\section{Kaynaklar}

[1] Khanna-Chopra R., Selote D.S., "Acclimation to drought stres generates oxidative stress tolerance in drought resistant than susceptible wheat cultivar under field conditions" Environmental and Experimental Botany, 60, 276-283, 2007

[2] Sevgican, A., Örtüaltı Sebzeciliği (Topraksız Tarım). Ege Üniversitesi, Ziraat Fakültesi Yayınları No: 526, 476s, Bornova, İzmir, 1999

[3] Winsor, G.W., Schwarz M., 1990. Soilless culture for Horticultural Crop Production. FAO Plant Production and Protection Paper, No: 101, Rome, pages 188, 2007

[4] Schwarz M., " Soilless Culture Management in Advanced Series in Agricultural Sciences” 24, Edited by McNeal B.L., Tardieu F., Van Keulen H., Van Vleck D., Springer-Verlag Berlin Heidelberg, 147-156, 1995

[5] Jensen, M.H., “Hydroponics” Hortscience, 32(6) 1997

[6] http://www.tuik.gov.tr

[7] Bayraktar K., Sebze Yetiştirme “Kültür Sebzeleri”. E.Ü.Zir.Fak., Cilt 2, Yayın No: 169, İzmir. 1970

[8] Vural, H., Eşiyok, D., Duman İ., Kültür Sebzeleri (Sebze Yetiştirme). Ege Üniversitesi Basım Evi, 404s, Bornova, İzmir, 2000

[9] Stuart N.W., “ Growing plants without soil” Science, Monthly 66, 273-282. 1948

[10] Gauch, H.G., Inorganic Plant Nutrition. Straudsburg, PA.: Dowden, Hutchinson and Ross. Inc., USA; P: 305-332. 488s, 1972

[11] Culbertson, R.E., Nakayama T., Hiramatsu M., "Hydroponic vegetable production in Japon-An operation of the U.S. Army Quartermaster Crops” Market Growers Journal 86: 16-19, 1957 
[12] Soundy P., Smith, I.E., "Evaluation of lettuce (Lactuca sativa L.) cultivars in the Natal midlands” Journal of Science African Society for Horticultural Science 2(1), 46-49, 1992

[13] Maboko M.M., Du Plooy C.P., "Production of crisphead lettuce in a soilless production system” African Crop Science Proceedings 8: 319-325, 2007

[14] Wurr, D.C.E., Fellows, J.R., Phelps, K., "Investigating trends in vegetable crop response to increasing temperature associated with climate change” Scientia Horticulture, 66,255-263, 1996

[15] Maboko M.M., Du Plooy C.P., "Effect of plant spacing on growth and yield of lettuce (Lactuca sativa L.) in a soilless production system” South African Journal of Plant and Soil, 26(3), 199201, 2009

[16] Ercan, N., Bayyurt R., "The effects of applications which increase the $\mathrm{O}_{2}$ of the water on yield and quality of lettuce grown in a floating system" Acta Horticulturae, 1034, 77-84, 2013.

[17] Toth N., Fabek S., Benko B., Segon P., Zutic I., Stuljar S., "Cultivar and Plant Density Impact on Growth and Morphometric Characteristics of Lettuce in Floating System." 6th Balkan Symposium on Vegetables and Potatoes, Zagrep, Hırvatistan, 29 Eylül - 2 Ekim 2014

[18] Madzivhandila L.L.R., "Crisphead Lettuce Cultivar Evaluation and Response of Transplant to Nitrogen Nutrition” University of Pretoria, M Inst Agar, Msc Thesis, 52s, Pretoria, South Africa, 2005

[19] Maboko M. M., Du Plooy C. P., "Evaluation of crisphead lettuce cultivars (Lactuca sativa L.) for winter production in a soilless production system” African Journal of Plant Science 2 (10), 113-117, 2008

[20] Scuderi D., Giuffrida F., Noto G., "Effects of salinity and plant density on quality of lettuce grown in floating system for fresh-cut” Acta horticulturae, 843, 219-226, 2009 